\title{
AMS RADIOCARBON DATES OF KURGANS LOCATED ON THE UST'-YURT PLATEAU, UZBEKISTAN
}

\author{
Soren Blau \\ Southbank, Victoria 3006, Australia. Corresponding author. Email: sorenb@vifm.org. \\ Vadim Yagodin \\ Institute of History, Archaeology and Ethnography, Nukus, Uzbekistan.
}

Department of Archaeology, Flinders University. Also: The Victorian Institute of Forensic Medicine, 57-83 Kavanagh St,

\begin{abstract}
Recent osteological analyses of archaeological human skeletal remains from the Ust'-Yurt Plateau, Uzbekistan, provided the opportunity to obtain samples for radiocarbon dating. The results of 18 accelerator mass spectrometry (AMS) dates are presented in this paper and provide the first absolute dates for late prehistoric and early historic archaeological sites in Uzbekistan. The AMS dates suggest that most sites are earlier than have been traditionally thought based on relative dating using artifact typologies.
\end{abstract}

\section{INTRODUCTION}

Russian scholarship in Central Asia has traditionally concentrated on the examination of archaeologically defined domestic areas and material culture as a means of interpreting whether remains belonged to nomadic or sedentary peoples (e.g. Belentisky 1968; Frumkin 1970). The evidence recovered from excavations of cemeteries has been used primarily to investigate religious beliefs and to ascertain social structures. Descriptions of modes of interment are also prominent in the literature, particularly early burials from northern Afghanistan, southern Tajikistan, and southern Uzbekistan. The majority of sites dating to the later prehistoric period in these countries are only relatively dated and have been placed at the end of the 2nd millennium BC (the Bronze Age) and the beginning of the 1st millennium BC (e.g. Abetekov and Yusupov 1994; Masson 1992). Little, however, is known about cemeteries in northwestern Uzbekistan, which are only relatively dated to the later so-called "Antique" period, which includes the Archaic period (7th-5th century BC), Kangiui period (4th century $\mathrm{BC}-1$ st century $\mathrm{AD}$ ), and Kushan period (1st-3rd century $\mathrm{AD}$ ) (Helms and Yagodin 1997). The recent formation of the Karakalpak-Australian Expedition ${ }^{1}$ has provided the opportunity to address this gap in knowledge by making available material from a number of burial mounds (kurgans) from the Ust'-Yurt Plateau, northwestern Uzbekistan.

Our research project aims to use morphological and isotopic analyses of osteological remains from kurgans located on the Ust'-Yurt Plateau to investigate past population health and migration patterns in western Uzbekistan. In addition, scientific dating of the kurgans is being undertaken to augment the interpretation of the osteological findings. This paper presents the results of the dating program.

\section{DESCRIPTIVE BACKGROUND}

The Ust'-Yurt Plateau is located between the Aral Sea and an inlet of the Caspian Sea $\left(58^{\circ} 15^{\prime} \mathrm{E}\right.$, $44^{\circ} 10^{\prime} \mathrm{N}$ ) and spans the southern part of Kazakhstan, the northern part of the Karakalpak Republic (Uzbekistan), and Turkmenistan (Figure 1). The Ust'-Yurt Plateau covers an area of $160,600 \mathrm{~km}^{2}$ and rises to 150-300 m above sea level (Anonymous 2002). The Plateau consists of a monotonous desert with large drainage basins and extensive sandy upland massifs. With the exception of sweet

\footnotetext{
${ }^{1}$ The Karakalpak-Australian Expedition was formed under the auspices of the University of Sydney Central Asian Project (USCAP) by Dr Alison Betts and Dr Svend Helms (Department of Archaeology, University of Sydney) and Prof Vadim Yagodin (Director of the Institute of History, Archaeology and Ethnography [IHAE], Nukus, Uzbekistan).
} 


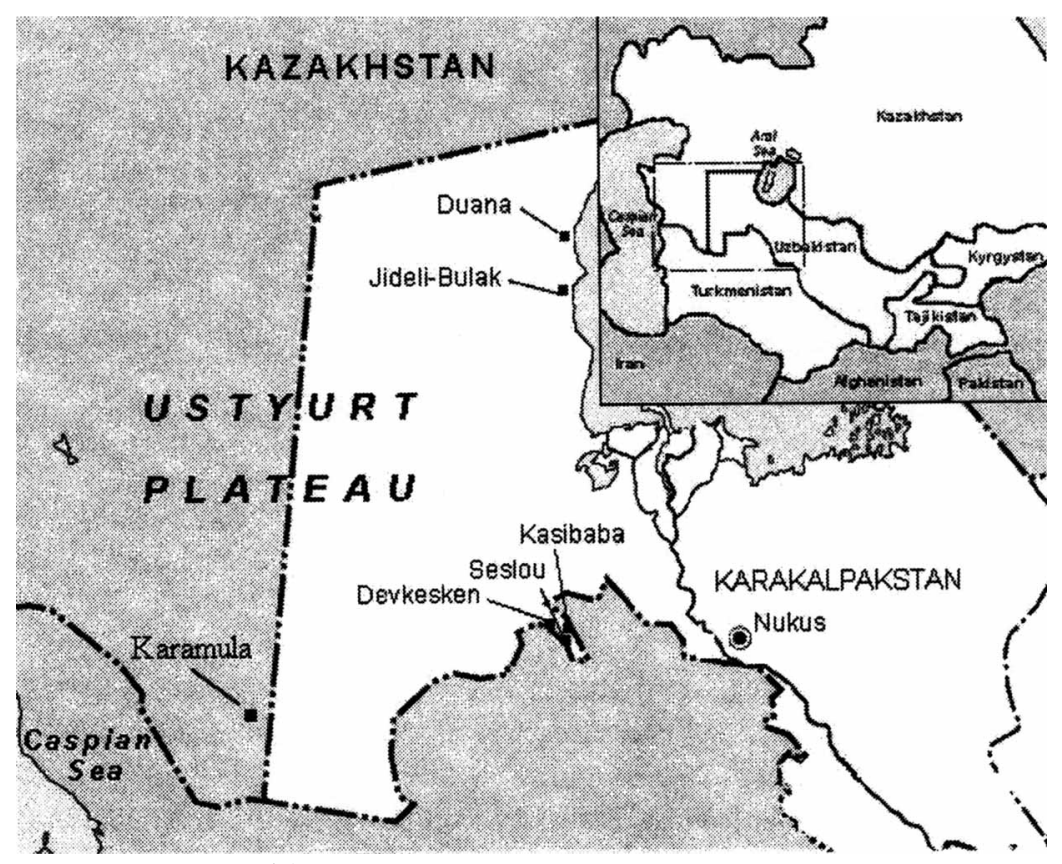

Figure 1 Location of the Ust'-Yurt Plateau

and salty water that is accessible from deep wells, there are few water resources and a lack of mature vegetation. The average annual rainfall ranges from $90 \mathrm{~mm}$ in the south to $120 \mathrm{~mm}$ in the north. The plateau has a continental climate with recorded summer temperatures reaching up to $47^{\circ} \mathrm{C}$ and lows of $-30{ }^{\circ} \mathrm{C}$ in the winter (Yagodin, forthcoming). The climatic conditions on the Ust'-Yurt are claimed to have changed little over the last 3000 yr (e.g. Olkhovskiy 2000:34), although further research in this field is required.

An extensive program of archaeological research on the Ust'-Yurt Plateau was undertaken between 1972 and 1985 under the direction of Professor Vadim Yagodin (IHAE), Karakalpak Branch of the Uzbek Academy of Science, Nukus. Large cemetery sites including Devkesken, Kazibaba, Duana, Sesilou, and Jideli Bulak were recorded (see Figure 1). Due to time restraints, within each site specific areas were selected for investigation (e.g. Devkesken 6, Kazibaba 4, Duana 5). Depending on the degree of preservation, at some sites samples of the better preserved kurgans were selected for excavation (e.g. 19 out of the 58 kurgans at Devkesken 6), while at other sites with improved preservation all kurgans were excavated (e.g. all 72 kurgans at Kazibaba 4). Kurgans from all sites were relatively dated based on associated artifacts (Table 1 ).

Table 1 Relative dates for Ust'-Yurt Plateau sites.

\begin{tabular}{ll}
\hline Site & Relative date \\
\hline Kazibaba 3 & 6th/5th century BC \\
Kazibaba 5 & 6th/5th century BC \\
Kazibaba 6 & 6th/5th century BC \\
Kazibaba 2 & 4th/3rd century BC \\
Karamala 1 & 4th/3rd century BC \\
Kazibaba 4 & 3rd/4th century AD \\
Devkesken 6 & 3rd/4th century AD \\
Duana & 3rd/4th century AD \\
\hline
\end{tabular}


Evidence from the excavations illustrates that the burial practices of the late prehistoric and early historic populations using the Ust'-Yurt Plateau involved placing one person, but sometimes up to 12 individuals, inside a subterranean pit. The pits ranged between 0.30 to $1.4 \mathrm{~m}$ in depth and were covered with stones to form a mound (kurgan). Craniometric and osteometric analyses of some of the human remains from sites on the plateau have been undertaken (Bagdasarova 1993) and preliminary results of the morphological skeletal analyses have revealed evidence of leprosy in Central Asia during the time period investigated (Blau and Yagodin 2005). The results of oxygen and strontium isotopic analyses are currently being interpreted.

\section{METHODS}

All archaeological skeletal remains recovered from the Ust'-Yurt Plateau are currently housed in the Karakalpak Museum, Nukus. Soren Blau visited the museum in 2003 and 2004 to undertake osteological analyses of the remains. Samples of complete permanent and deciduous human teeth were collected for radiocarbon dating from 18 individuals to enhance the interpretations of osteological and isotopic analyses. No other organic samples were dated due to the lack of preservation.

The dental samples come from 7 separate kurgans at 5 sites. A total of 4 dates were obtained from Kurgan 2, Kazibaba 3, which had a minimum of 16 individuals interred. One adult and 3 teenagers were sampled, i.e. a total of 4 individuals. Three kurgans from Kazibaba 4 were dated. A total of 2 adults were interred in both Kurgan 11 and Kurgan 24. Two tooth samples were obtained from 1 adult from Kurgan 11 and 1 sample from 1 adult from Kurgan 24. Only 1 individual (an adult) was buried in Kurgan 22 and 1 tooth sample was obtained from this individual.

Two kurgans from Kazibaba 6 were dated. Kurgan 2 had a total of 14 individuals (9 adults and 5 children) and Kurgan 5 contained 12 individuals ( 7 adults and 5 children). A total of 7 dates representing at least 2 adults were obtained from Kurgan 5, while 1 sample from 1 adult was obtained from Kurgan 2. Kurgan 3, Devkesken 6 and Kurgan 2, Karamula 1 both had 1 adult each interred in them. Due to funding procedures, samples were submitted to 3 separate dating laboratories: Oxford Radiocarbon Accelerator Unit, Beta Analytic Inc., and the Australian Nuclear Science and Technology Organisation (ANSTO).

\section{RESULTS AND DISCUSSION}

Kurgans on the Ust'-Yurt Plateau have traditionally been dated using relative dates based on artifact typology (e.g. Jagodin 1987). The AMS dates presented in this paper are the first absolute dates for archaeological sites on the Ust'-Yurt Plateau (Table 2). Four dates from Kurgan 2, Kazibaba 2 were obtained which suggest the site was in use between the $9 / 8$ th to the $6 / 5$ th centuries BC. These results are significantly earlier than the relative dates (see Table 1).

Three kurgans from Kazibaba 4 were dated. The 2 dates from Kurgan 11 and 1 date from Kurgan 24 suggest the site dates between the 2 nd century BC and the 1 st century AD. These results are slightly earlier than the relative dates (see Table 1). The 2 dates from Kurgan 11 were obtained from 1 individual and their close correspondence highlights the reliability of AMS as a dating method. The 1 date from Kurgan 22 suggests this kurgan was used between the 6th-5th century BC. While it is possible that this date is an anomaly, given there are other kurgans at Kazibaba that were in use as early as the 10th century BC (see below), an early use of Kurgan 22 is probable.

Two kurgans from Kazibaba 6 were dated. A total of 7 dates were obtained from Kurgan 5 which suggest this kurgan was in use between the 10th-9th and the 8th-5th centuries BC. Although only 1 date was obtained for Kurgan 2, the result is consistent with the site being in use between the 8th and 
Table 2 AMS date results of human teeth samples.

\begin{tabular}{|c|c|c|c|c|c|}
\hline Lab code & $\begin{array}{l}\text { Site/Kurgan/ } \\
\text { Sample ref. }\end{array}$ & $\begin{array}{l}{ }^{14} \mathrm{C} \text { age } \\
\text { (BP) }\end{array}$ & $\begin{array}{l}95.4 \% \text { cal } \\
\text { age ranges } \\
(2 \sigma)\end{array}$ & $\begin{array}{l}\text { Relative } \\
\text { area under } \\
\text { distribution }\end{array}$ & $\begin{array}{l}{ }^{13} \mathrm{C} \\
(\%)\end{array}$ \\
\hline Beta-190243 & $\begin{array}{l}\text { Kazibaba } 3 \\
\text { Kurgan } 2 \\
\text { Sample T15 }\end{array}$ & $2450 \pm 40$ & $\begin{array}{r}\text { cal BC } 761-679 \\
670-610 \\
596-407\end{array}$ & $\begin{array}{l}0.275 \\
0.147 \\
0.579\end{array}$ & -13.8 \\
\hline Beta-190244 & $\begin{array}{l}\text { Kazibaba } 3 \\
\text { Kurgan } 2 \\
\text { Sample T16 }\end{array}$ & $2630 \pm 40$ & $\begin{array}{r}\text { cal BC } 896-871 \\
864-847 \\
844-762 \\
677-673\end{array}$ & $\begin{array}{l}0.052 \\
0.020 \\
0.921 \\
0.006\end{array}$ & -15.4 \\
\hline Beta-190245 & $\begin{array}{l}\text { Kazibaba } 3 \\
\text { Kurgan } 2 \\
\text { Sample T17 }\end{array}$ & $2560 \pm 40$ & $\begin{array}{r}\text { cal BC } 814-755 \\
722-539 \\
528-523\end{array}$ & $\begin{array}{l}0.423 \\
0.573 \\
0.004\end{array}$ & -14.4 \\
\hline $\begin{array}{l}\text { ANSTO- } \\
\text { 0ZH093 }\end{array}$ & $\begin{array}{l}\text { Kazibaba } 3 \\
\text { Kurgan } 2 \\
\text { Sample T27 }\end{array}$ & $2520 \pm 50$ & $\begin{array}{r}\text { cal BC } 799-502 \\
490-484 \\
465-449 \\
440-427 \\
423-413\end{array}$ & $\begin{array}{l}0.943 \\
0.008 \\
0.020 \\
0.018 \\
0.011\end{array}$ & -14.2 \\
\hline Beta-190246 & $\begin{array}{l}\text { Kazibaba } 4 \\
\text { Kurgan } 11 \\
\text { Sample T39 }\end{array}$ & $2000 \pm 40$ & $\begin{array}{c}\text { cal BC } 105-102 \\
95-\text { cal AD } 84 \\
\text { cal AD 104-118 }\end{array}$ & $\begin{array}{l}0.002 \\
0.984 \\
0.014\end{array}$ & -19.9 \\
\hline Beta-190247 & $\begin{array}{l}\text { Kazibaba } 4 \\
\text { Kurgan } 11 \\
\text { Sample T80 }\end{array}$ & $2050 \pm 40$ & $\begin{array}{l}\text { cal BC 169-cal AD } 27 \\
\text { cal AD 42-49 }\end{array}$ & $\begin{array}{l}0.986 \\
0.014\end{array}$ & -20.9 \\
\hline OxA-11822 & $\begin{array}{l}\text { Kazibaba } 4 \\
\text { Kurgan } 22 \\
\text { Nr } 198 \\
\text { Sample } 14\end{array}$ & $2425 \pm 30$ & $\begin{array}{r}\text { cal BC } 760-681 \\
666-637 \\
590-579 \\
548-401\end{array}$ & $\begin{array}{l}0.246 \\
0.041 \\
0.012 \\
0.701\end{array}$ & -17.4 \\
\hline OxA-11793 & $\begin{array}{l}\text { Kazibaba } 4 \\
\text { Kurgan } 24 \\
\text { Sample } 12\end{array}$ & $2096 \pm 24$ & $\begin{array}{c}\text { cal BC } 196-193 \\
174-46\end{array}$ & $\begin{array}{l}0.004 \\
0.996\end{array}$ & -20.6 \\
\hline $\begin{array}{l}\text { ANSTO- } \\
\text { 0ZH095 }\end{array}$ & $\begin{array}{l}\text { Kazibaba } 6 \\
\text { Kurgan } 2 \\
\text { Sample T57 }\end{array}$ & $2490 \pm 50$ & $\begin{array}{r}\text { cal BC } 787-482 \\
467-448 \\
442-412\end{array}$ & $\begin{array}{l}0.901 \\
0.039 \\
0.060\end{array}$ & -13.8 \\
\hline Beta-190248 & $\begin{array}{l}\text { Kazibaba } 6 \\
\text { Kurgan } 5 \\
\text { Sample T62 }\end{array}$ & $2760 \pm 40$ & $\begin{array}{r}\text { cal BC } 997-985 \\
983-828\end{array}$ & $\begin{array}{l}0.032 \\
0.968\end{array}$ & -16.9 \\
\hline Beta-190249 & $\begin{array}{l}\text { Kazibaba } 6 \\
\text { Kurgan } 5 \\
\text { Sample T72 }\end{array}$ & $2490 \pm 40$ & $\begin{array}{r}\text { cal BC } 786-498 \\
493-483 \\
465-449 \\
441-413\end{array}$ & $\begin{array}{l}0.909 \\
0.014 \\
0.030 \\
0.047\end{array}$ & -14.3 \\
\hline Beta-190250 & $\begin{array}{l}\text { Kazibaba } 6 \\
\text { Kurgan } 5 \\
\text { Sample T73 }\end{array}$ & $2620 \pm 40$ & $\begin{array}{r}\text { cal BC } 896-872 \\
863-848 \\
844-760 \\
681-667 \\
610-594\end{array}$ & $\begin{array}{l}0.031 \\
0.011 \\
0.924 \\
0.021 \\
0.013\end{array}$ & -17.6 \\
\hline Beta-190251 & $\begin{array}{l}\text { Kazibaba } 6 \\
\text { Kurgan } 5 \\
\text { Sample T74 }\end{array}$ & $2730 \pm 40$ & $\begin{array}{r}\text { cal BC 971-958 } \\
937-805\end{array}$ & $\begin{array}{l}0.036 \\
0.964\end{array}$ & -16.8 \\
\hline
\end{tabular}


Table 2 AMS date results of human teeth samples. (Continued)

\begin{tabular}{|c|c|c|c|c|c|}
\hline Lab code & $\begin{array}{l}\text { Site/Kurgan/ } \\
\text { Sample ref. }\end{array}$ & $\begin{array}{l}{ }^{14} \mathrm{C} \text { age } \\
(\mathrm{BP})\end{array}$ & $\begin{array}{l}95.4 \% \text { cal } \\
\text { age ranges } \\
(2 \sigma)\end{array}$ & $\begin{array}{l}\text { Relative } \\
\text { area under } \\
\text { distribution }^{\mathrm{a}}\end{array}$ & $\begin{array}{l}{ }^{13} \mathrm{C} \\
(\%)\end{array}$ \\
\hline $\begin{array}{l}\text { ANSTO- } \\
\text { 0ZH096 }\end{array}$ & $\begin{array}{l}\text { Kazibaba } 6 \\
\text { Kurgan } 5 \\
\text { Sample T75 }\end{array}$ & $2510 \pm 50$ & $\begin{array}{r}\text { cal BC } 796-499 \\
492-483 \\
465-449 \\
441-426 \\
424-413\end{array}$ & $\begin{array}{l}0.925 \\
0.012 \\
0.026 \\
0.021 \\
0.016\end{array}$ & -15.3 \\
\hline $\begin{array}{l}\text { ANSTO- } \\
\text { 0ZH097 }\end{array}$ & $\begin{array}{l}\text { Kazibaba } 6 \\
\text { Kurgan } 5 \\
\text { Sample T76 }\end{array}$ & $2400 \pm 50$ & $\begin{array}{r}\text { cal BC } 761-679 \\
669-626 \\
621-614 \\
593-572 \\
564-390\end{array}$ & $\begin{array}{l}0.224 \\
0.064 \\
0.007 \\
0.027 \\
0.677\end{array}$ & -13.1 \\
\hline $\begin{array}{l}\text { ANSTO- } \\
\text { 0ZH098 }\end{array}$ & $\begin{array}{l}\text { Kazibaba } 6 \\
\text { Kurgan } 5 \\
\text { Sample T77 }\end{array}$ & $2500 \pm 50$ & $\begin{array}{r}\text { cal BC } 791-483 \\
466-449 \\
441-413\end{array}$ & $\begin{array}{l}0.922 \\
0.030 \\
0.047\end{array}$ & -16.2 \\
\hline $\begin{array}{l}\text { ANSTO- } \\
\text { 0ZH094 }\end{array}$ & $\begin{array}{l}\text { Karamula } 1 \\
\text { Kurgan } 2 \\
\text { Sample T28 }\end{array}$ & $2120 \pm 50$ & $\begin{array}{c}\text { cal BC } 355-288 \\
257-247 \\
233-37 \\
31-20 \\
11-\text { cal AD } 0\end{array}$ & $\begin{array}{l}0.138 \\
0.010 \\
0.826 \\
0.012 \\
0.014\end{array}$ & -16.0 \\
\hline OxA-11792 & $\begin{array}{l}\text { Devkesken } 6 \\
\text { Kurgan } 3 \\
\text { Sample } 5\end{array}$ & $1854 \pm 26$ & $\begin{array}{r}\text { cal AD } 83-105 \\
116-237\end{array}$ & $\begin{array}{l}0.092 \\
0.908\end{array}$ & -13.6 \\
\hline Beta-190243 & $\begin{array}{l}\text { Kazibaba } 3 \\
\text { Kurgan } 2 \\
\text { Sample T15 }\end{array}$ & $2450 \pm 40$ & $\begin{array}{r}\text { cal BC } 761-679 \\
670-610 \\
596-407\end{array}$ & $\begin{array}{l}0.275 \\
0.147 \\
0.579\end{array}$ & -13.8 \\
\hline Beta-190244 & $\begin{array}{l}\text { Kazibaba } 3 \\
\text { Kurgan } 2 \\
\text { Sample T16 }\end{array}$ & $2630 \pm 40$ & $\begin{array}{r}\text { cal BC 896-871 } \\
864-847 \\
844-762 \\
677-673\end{array}$ & $\begin{array}{l}0.052 \\
0.020 \\
0.921 \\
0.006\end{array}$ & -15.4 \\
\hline Beta-190245 & $\begin{array}{l}\text { Kazibaba } 3 \\
\text { Kurgan } 2 \\
\text { Sample T17 }\end{array}$ & $2560 \pm 40$ & $\begin{array}{r}\text { cal BC } 814-755 \\
722-539 \\
528-523\end{array}$ & $\begin{array}{l}0.423 \\
0.573 \\
0.004\end{array}$ & -14.4 \\
\hline $\begin{array}{l}\text { ANSTO- } \\
\text { 0ZH093 }\end{array}$ & $\begin{array}{l}\text { Kazibaba } 3 \\
\text { Kurgan } 2 \\
\text { Sample T27 }\end{array}$ & $2520 \pm 50$ & $\begin{array}{r}\text { cal BC } 799-502 \\
490-484 \\
465-449 \\
440-427 \\
423-413\end{array}$ & $\begin{array}{l}0.943 \\
0.008 \\
0.020 \\
0.018 \\
0.011\end{array}$ & -14.2 \\
\hline
\end{tabular}

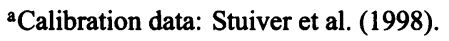

5th centuries BC. The AMS results suggest the site had multiple periods of use: some overlap with the relative dates (see Table 1), whereas others are significantly earlier.

The majority of human remains from Devkesken 6 were treated with a chemical preservative to consolidate the bones at the time of recovery. Consequently, it was only possible to obtain 1 untreated sample from Kurgan 3 . The results suggest the site was used between the 1 st-3rd centuries AD, that is, during the Kushan period (Helms and Yagodin 1997:47). This is slightly earlier than the relative dates, which placed the site between the $3 \mathrm{rd} / 4$ th centuries AD (e.g. Jagodin 1987). Similarly, 1 sam- 
ple from Kurgan 2 at Karamula 1 dated to the 3rd century BC. This is consistent with the age suggested by relative dating.

There are many kurgan complexes throughout Central Asia which have been dated to the 1st millennium BC, the so-called "Iron Age." The majority have, however, only been relatively dated on stylistic assessments of associated material culture: examples include kurgans in the North Black Sea region (Yablonsky 2000), the Transurals of western Siberia (Dyachenko et al. 2000; Hanks 2000; Kroll 2000; Davis-Kimball and Yablonsky 1996:7-8), and from southern Siberia (Murphy 2000). Therefore, the results presented in this paper add to the pool of scientifically dated kurgans in the region, including Pokrovka, southern Russia (Hall et al. 1998:546), and kurgans in the southern part of the Altai Mountains (Slusarenko et al. 2001).

\section{CONCLUSION}

Samples of human tooth were collected from skeletal assemblages stored in the Karakalpak Museum, Nukus, originating from burial sites on the Ust'-Yurt Plateau, Uzbekistan. A total of 18 AMS dates were obtained, providing the first absolute dates for late prehistoric and early historic archaeological sites in Uzbekistan. In most cases, the AMS analysis results indicate that the antiquity of the kurgans is earlier than traditionally thought based on relative dates.

AMS dates for individuals interred within single kurgans and for kurgans within single sites indicate multiple periods of use. Previous interpretations had considered an individual kurgan to represent a single event of use, and sites to represent a single period of use. These findings are significant as they alter the present understanding of the chronology of individual burial structures, as well as the sites of which they are a part. In addition, the results highlight the need for more absolute dating in the region to better calibrate the relative chronology.

\section{ACKNOWLEDGMENTS}

Funding for the preliminary field trip by Soren Blau to Uzbekistan (including 2 AMS dates) was provided by Bournemouth University. The 3-yr research project investigating the health and population movements of prehistoric communities in western Central Asia is funded by the Australian Research Council. Additional funding for dating was provided by ANSTO (Grant 04/190). We are grateful to Tim Denham for useful comments on the content of this paper.

\section{REFERENCES}

Abetekov A, Yusupov H. 1994. Ancient Iranian nomads in western Central Asia. In: Harmatta J, editor. History of Civilizations of Central Asia. The Development of Sedentary and Nomadic Civilizations $700 B C$ to $A D$ 250. Volume 2. Paris: UNESCO Publishing. p 23-33. Anonymous. 2002. Ustyurt. The Columbia Electronic Encyclopedia, 7th edition. Columbia University Press. URL: <http://www.encyclopedia.com/>. Accessed 2 March 2003.

Bagdasarova NA. 1993. Kochevniki yugo-zapadnogo Priaralia $v 1$ tysyacheletii do nashei ery-1 tysyacheletii nashei ery (po antropologicheskim dannym). (Nomads of the southwestern Aral Sea area in 1st millennium $\mathrm{BC}-1$ st millennium $\mathrm{AD}$ [according to anthropological data]) [PhD dissertation]. Moscow: Department of Anthropology, Institute of Ethnology and
Anthropology. Museum of Anthropology of Moscow State University. English translation by S Amirov.

Belentisky A. 1968. Central Asia. Geneva: Nagel Publications. p 15-25.

Blau S, Yagodin V. 2005. Osteoarchaeological evidence for leprosy from western Central Asia. American Journal of Physical Anthropology 126:150-8.

Davis-Kimball J, Yablonsky L. 1996. Excavations of kurgans in the southern Orenburg district, Russia: questions concerning the northern Silk Route. Silk Road Art and Archaeology 4:1-16.

Dyachenko AN, Skripkin AS, Klepikov VM, Kubyshkin AI, Mabe A. 2000. Excavations of the Aksai kurgans in the Volga-Don region (Russia). In: Davis-Kimball J, Murphy EM, Koryakova L, Yablonsky LT, editors. Kurgans, Ritual Sites and Settlements: Eurasian 
Bronze and Iron Age. British Archaeological Reports International Series 890:43-62.

Frumkin G. 1970. Archaeology in Soviet Central Asia. Lieden: EJ Brill.

Hall ME, Brimmer SP, Li F-H, Yablonsky L. 1998. ICPMS and ICP-OES studies of gold from a Late Sarmatian burial. Journal of Archaeological Science 25: 545-52.

Hanks B. 2000. Iron Age nomadic burials of the Eurasian steppe: a discussion exploring burial ritual complexity. In: Davis-Kimball J, Murphy EM, Koryakova L, Yablonsky LT, editors. Kurgans, Ritual Sites and Settlements: Eurasian Bronze and Iron Age. British Archaeological Reports International Series 890:19-30.

Helms S, Yagodin VN. 1997. Excavations at Kazakl' IYatkan in the Tash-ki'rman oasis of ancient Chorasmia: a preliminary report. Iran 35:43-65.

Jagodin V. 1987. Les sépultures á ostothèques sur les marges nord-ouest de la Chorasmie antique. In: Grenet $F$, editor. Cultes et monuments religieux dans l'Asie Central préislamique. Mémoire no. 2 des publications de l'UA 1222. Paris: CNRS. p 11-22.

Kroll A-M. 2000. Looted grave or burials without bodies? In: Davis-Kimball J, Murphy EM, Koryakova L, Yablonsky LT, editors. Kurgans, Ritual Sites and Settlements: Eurasian Bronze and Iron Age. British Archaeological Reports International Series 890:215-22.

Masson VM. 1992. The decline of the Bronze Age civilization and movements of the tribes. In: Dani AH, Masson VM, editors. History of Civilizations of Central Asia: The Dawn of Civilization: Earliest Times to 700 BC. Volume 1. Paris: UNESCO Publishing. p 477-80.

Murphy EM. 2000. Mummification and body processing: evidence from the Iron Age in southern Siberia. In: Davis-Kimball J, Murphy EM, Koryakova L, Yablonsky LT, editors. Kurgans, Ritual Sites and Settlements: Eurasian Bronze and Iron Age. British Archaeological Reports International Series 890:279-92.

Olkhovskiy VS. 2000. Ancient sanctuaries of the Aral and Caspian regions: a reconstruction of their history. In: Davis-Kimball J, Murphy EM, Koryakova L, Yablonsky LT, editors. Kurgans, Ritual Sites and Settlements: Eurasian Bronze and Iron Age. British Archaeological Reports International Series 890:33-42.

Slusarenko IY, Christen JA, Orlova LA, Kuzmin YV, Burr GS. 2991. ${ }^{14} \mathrm{C}$ wiggle matching of the "floating" tree-ring chronology from the Altai Mountains, southern Siberia: the Ulandryk-4 case study. Radiocarbon 43(2A):425-31.

Stuiver M, Reimer PJ, Bard E, Beck JW, Burr GS, Hughen KA, Kromer B, McCormac FG, van der Plicht J, Spurk M. 1998. IntCal98 radiocarbon age calibration, 24,000-0 cal BP. Radiocarbon 40(3):1041-83.

Yagodin VN. Forthcoming. The Duana archaeological complex. In: Yagodin VN, Betts AVG Helms S, editors. The Ancient Nomads of the Aralo-Caspian Region: The Duana Archaeological Complex. Sheffield: Sheffield Archaeological Monographs, JR Collis Publications.

Yablonsky LT. 2000. "Scythian Triad" and "Scythian World.” In: Davis-Kimball J, Murphy EM, Koryakova L, Yablonsky LT, editors. Kurgans, Ritual Sites and Settlements: Eurasian Bronze and Iron Age. British Archaeological Reports International Series 890:3-8. 